\title{
EDITORIAL
}

\section{Vozes d'além-mar}

A ideia deste dossiê surgiu de uma série de discussões realizadas durante o XVI Congresso Internacional da Abralic, cujo tema foi "Circulação, Tramas \& Sentidos na Literatura", realizado na Universidade Federal de Uberlândia-UFU, entre os dias 30 de julho e 03 de agosto de 2018. Naquela ocasião, inscritos no simpósio intitulado "Vozes d'além-mar" e afinados com um mesmo propósito, o de perscrutar caminhos palmilhados em torno da alteridade materializada nas mais diferentes manifestações literárias, professores e pós-graduandos ligados a diversas áreas das letras aproximaram-se, divulgando seus trabalhos, expondo suas inquietações e vislumbrando perspectivas. Reflexões profundas e inovadoras, versando mormente sobre especificidades do romance e da lírica se fizeram sentir, já apontando para a ubiquidade de um tema que continuaria a ressoar sobretudo na importância de se estar atento à constituição do olhar sobre o Outro e às artimanhas do poder que subjazem ao mesmo.

Dessarte, a Revista Jangada abriu espaço para a acolhida de trabalhos de estudiosos interessados em dialogar com o tema do simpósio. O resultado foi uma recepção plural, constituindo-se não só de reflexões em interlocução com o tema, mas também de assuntos versando sobre registros ligados ao gênero no processo de tradução de autoras francesas para a língua espanhola, por exemplo. A pertinência da temática manteve-se vigorosa, perpassando estudos que consideram desde o mito de Cleópatra, a representação do feminino na literatura e seu lugar na ópera italiana, até o teatro de bonecos, a estética do conto e o absurdo camusiano, transpondo assim os territórios d'aquém e d'além-mar.

“L'esprit féminin du siècle des Lumières dans les lettres espagnoles: Louise d'Épinay, Anne-Thérèse de Lambert et Marie de Rabutin-Chantal (Madame de Sévigné)”, de Beatriz Onandía Ruiz, abre-se este número. A autora nos apresenta um panorama crítico dos padrões da educação e da moralidade no seio dos círculos mais elitistas da Espanha do século XVIII. 
Ao cotejar traduções do francês, feitas à época com fins didáticos para este público alvo, várias inserções e/ou supressões ligadas à formação da subjetividade feminina são curiosamente trazidas à tona, fazendo repensar o escopo de tais manobras literárias.

Carmen Lojo Tizón, por sua vez, em 'Le mythe de Cléopâtre dans L'Heure sexuelle (1898) de Rachilde", analisa a reescritura do mito de Cleópatra no romance L'Heure sexuelle da escritora francesa Rachilde (1860-1953) a partir de uma relação intertextual da figura mítica da rainha egípcia com uma jovem prostituta do fin de siècle parisiense. Tizón demonstra visão arguta ao refletir sobre a maneira como Rachilde tece sua teia romanesca dentro dos princípios do imaginário da decadência francesa.

Dando sequência à relação entre o espírito (imaginário) de uma época e as vozes literárias através das quais este se manifesta, chegamos à reflexão de Danilo Rodrigues Pimenta em "O absurdo camusiano em O Mito de Sísifo". Neste, Pimenta discorre sobre os três ciclos do pensamento de Albert Camus, a saber, o lirismo, o absurdo e a revolta, e nos abre a percepção para a relação entre o homem e o mundo, mais precisamente em $O$ mito de Sísifo. Desse modo, buscamos compreender como o franco-argelino descreveu em seu ensaio sobre o absurdo, a relação de divórcio entre o homem e o mundo, constatada pela sensibilidade e esclarecida pela razão, nomeada de sentimento do absurdo e noção do absurdo, respectivamente.

Em favor da função poética aristotélica, Cristina Oliveira Ramos em uma abordagem crítica do uso de perspectivas temático-discursivas do texto em "A estética do conto de Lília Momplé: do poder catártico da palavra à perpetuação" examina dois contos que integram a obra Os olhos da cobra verde, de Lília Momplé. Ramos visa salientar além das linhas temáticas patentes nessas narrativas breves, os traços formais, as características discursivas e o modo de exposição, tratamento e formulação das perspectivas do narrador, relacionando-os entre si, de maneira a enfatizar não só o poder catártico da palavra, mas também a perpetuação, alcançada através da escrita, da memória moçambicana.

Como não poderia deixar de ser, o nome de Antônio José da Silva, o Judeu, surge-nos como uma cara contribuição ao panorama da crítica da alteridade. Jorge Luís Oliveira reflete sobre sua importância no contexto do teatro de marionetes e do teatro em língua portuguesa em geral. Tal forma de fazer teatro com bonecos percorreu os tempos chegando até aos dias de hoje e, nota-se, a partir da reflexão de Oliveira em "O legado Jangada | nr. 12, jul/dez, 2018 | ISSN 2317-4722 
dos bonecos de varão de António José da Silva, O Judeu", que a evolução da estrutura dramatúrgica e a técnica de construção e manipulação usada no teatro do Judeu encontram ressonâncias, ainda hoje, no interior sul de Portugal continental, nos assim designados, Bonecos de Santo Aleixo.

Do teatro à lírica, adentramos solo brasileiro em “A representação do feminino pelo flâneur em 'Mulheres', de Marcelo Gama”, de autoria de Elisa Seering e Cecil Jeanine Albert Zinani que, neste ensaio, discutem o poema "Mulheres", do poeta gaúcho Marcelo Gama, publicado na revista Fon-Fon!, no Rio de Janeiro de 1913. A leitura das pesquisadores destaca aspectos da flaneurie baudelairiana que permeiam o poema de Gama, revelando um observador crítico que circula pela avenida, assim como as já célebres mulheres passantes. Análise, diga-se, em que o sujeito-lírico desvela aspectos simbólicos da urbanidade.

Adentrando a fronteira da memória, Simone Pinheiro Achre recupera a obra póstuma de Wilson Bueno em seu artigo "A escrita de si como mecanismo de memória em Mano, a noite está velha, de Wilson Bueno". Achre perscruta a construção de um narrador-personagem, que se propõe revelar-se a si mesmo em uma "conversa no escuro", disposição que resulta em um texto cuja narrativa revela-se híbrida. Memórias da vida do protagonista e fatos do quotidiano são destacados por Achre, que realça o ato de escrever como um "conhecer-se a si mesmo".

Finalizando o dossiê, Isabel Viana apresenta uma reflexão de caráter interdisciplinar em "O papel da mulher na ópera italiana do século XIX”. Nesse artigo, Viana reflete sobre as óperas produzidas na Itália ao longo do século XIX, demonstrando como estas refletiam o papel desempenhado pela mulher na sociedade, malgrado a intensificação das emoções, atitudes e comportamentos próprios das artes.

Na sequência, trazemos o conto "Sra. Fønss", de Jeans Peter Jacobsen, em tradução comentada. Vertido do dinamarquês para o português por Ludmila Menezes Zwick e Renato Zwick, o conto de Jacobsen em língua pátria revela-se ótima oportunidade para o leitor brasileiro conhecer não só o próprio autor, mas um cadinho da literatura escandinava.

Por fim, trazemos a entrevista com o Professor Francisco Topa, da Universidade do Porto, realizadas pelos Professores Joelma Santa Siqueira e Dirceu Magri. Topa, leciona nas áreas Literatura e Cultura Brasileiras, Crítica Textual, Literaturas Africanas de Língua Portuguesa e Literaturas Orais e Marginais, o que só mostra que tem muito a dizer sobre a 


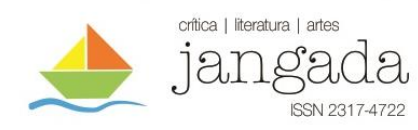

interlocução das literaturas e as vozes d'além-mar, expressão que, como nos alerta, requer atenção para que não estejamos a considerar as vozes dos escritores como provenientes de um mundo outro.

Certos de que a diversidade dos estudos aqui apresentados consolidam a Revista Jangada como veículo de expressão das Literaturas e das Humanidades, desejamos aos leitores uma ótima leitura!

Gracia Regina Gonçalves Juan Filipe Stacul Editores deste número 